\title{
FACTORS INFLUENCING SURGICAL OUTCOME OF MYRINGOPLASTY IN TUBOTYMPANIC TYPE OF CHRONIC OTITIS MEDIA
}

\author{
Bibhuti Das ${ }^{1}$ Debajit Das ${ }^{2}$ \\ ${ }^{1}$ Registrar, Department of ENT, FAAMCH, Barpeta, Assam. \\ 2 Professor and HOD, Department of ENT, AMCH, Dibrugarh, Assam.
}

\begin{abstract}
\section{BACKGROUND}

Chronic otitis media is an inflammatory process of the mucoperiosteal lining of the middle ear space and mastoid. Infection of the middle ear has been a problem encountered in the human race, and is as old as humanity itself. Chronic suppurative otitis media (CSOM) is one of the most common causes of ear infection in developing countries particularly in South-east Asian countries. Chronic middle ear disease is a major problem in India especially in the rural areas. It is estimated that 6\% of Indian population suffers from chronic ear disease. The term "Tubotympanic disease" is sometimes used to describe COM with a central perforation. The two principal aims of management of tubotympanic chronic otitis media are the eradication of infection and improvement of hearing by the closure of the tympanic membrane perforation which can be achieved either conservatively or by surgery. The surgical treatment of CSOM is still controversial. Some surgeons advice only repair of central perforation of tympanic membrane in non-cholesteatomatous tubotympanic chronic otitis media using graft i.e. myringoplasty to achieve a dry ear with improved hearing. This study aims to determine the factors responsible for successful surgical outcome of myringoplasty.
\end{abstract}

\section{MATERIALS AND METHODS}

This hospital-based prospective study was done in the Dept. of ENT, Assam Medical College and Hospital, Dibrugarh from $1^{\text {st }}$ January 2015 to 31 st December 2015 in diagnosed cases of tubotympanic variant of CSOM. Thirty patients were included in this study after fulfilling inclusion and exclusion criteria. The surgical outcomes were assessed in terms of hearing gain, graft uptake and dryness of ear.

\section{RESULTS}

Thirty patients of tubotympanic type of CSOM reviewed in the study with mean age group of $35.16 \pm 12.75$ years underwent myringoplasty. Successful graft uptake post-operatively at $3^{\text {rd }}$ followup (12 ${ }^{\text {th }}$ week) was seen in $83.33 \%$. Dry ear was achieved at the end of $12^{\text {th }}$ week in $86.67 \%$ and gain in hearing at $3^{\text {rd }}$ post-operative review was $9.90 \pm 1.81 \mathrm{~dB}$. 5 cases had graft failure, 4 cases failed to achieve dry ear. Extremity of ages, lower socio-economic status, postoperative URTI and ET dysfunction, disease in contralateral ear were associated factors in determining graft uptake and dry ear.

\section{CONCLUSION}

Myringoplasty has been established as a very effective surgical management of tubotympanic variant of CSOM. Success of myringoplasty can be measured in terms of gain in hearing, graft uptake and dry ear. Our study acknowledges that successful outcome of surgery is determined by a range of factors like lower socio-economic status particularly in rural population with unhygienic living conditions, presence of nidus of infection in the upper airway along with eustachian tube dysfunction, otitis externa, disease in contralateral ear may be considered as some of the possible factors responsible for influencing the outcomes of surgery in tubotympanic type of chronic otitis media. But we emphasised that more cases or study population for longer duration should be conducted to draw a conclusion.

\section{KEYWORDS}

Chronic Otitis Media, Tubotympanic Type, Myringoplasty.

HOW TO CITE THIS ARTICLE: Das B, Das D. Factors influencing surgical outcome of myringoplasty in tubotympanic type of chronic otitis media. J. Evolution Med. Dent. Sci. 2017;6(49):3797-3804, DOI: 10.14260/Jemds/2017/821
BACKGROUND
Chronic otitis media is an inflammatory process of the mucoperiosteal lining of the middle ear space and mastoid. Infection of the middle ear has been a problem encountered in the human race, and is as old as humanity itself. Even with
Financial or Other, Competing Interest: None.
Submission 13-04-2017, Peer Review 07-06-2017,
Acceptance 12-06-2017, Published 19-06-2017.
Corresponding Author:
Dr. Bibhuti Das,
C/o. Amiya Kumar Das,
House No. 143, Saurav Nagar,
Beltola, Guwahati-781028,
Dist. Kamrup Metro, Assam.
E-mail: drbibhutidas9@gmail.com
DOI: $10.14260 /$ jemds $/ 2017 / 821$
advent of newer antibiotics and better health facilities, chronic otitis media is still a widely encountered clinical entity in our country. It is estimated that $6 \%$ of Indian population suffers from chronic ear disease.1, 2 The recent study shows prevalence of chronic otitis media in rural Indian population is 46 per 1000 and in urban population is 16 per $1000 .^{3}$
Although CSOM is a major health problem in many indigenous populations around the world, its impacts are often more pronounced in developing countries despite the advances in Medicare recorded in the surgical management of CSOM globally. Risk factors that have been attributed to the high rates of CSOM in these populations are: overcrowding, poor hygiene, poor nutrition, high rates of nasopharyngeal colonisation with potentially pathogenic bacteria and inadequate and unavailable health care. ${ }^{3}$ 
A consequence of CSOM is hearing loss and a propensity to recurrent infection and discharge. ${ }^{4}$ With the greater advent of diagnostic tools it has become easier to diagnose and classify different types of chronic otitis media. Similarly, with easier availability of medicines and advanced surgical procedures, the management of chronic otitis media has become easier.

However, in developing nation like India \& particularly in Assam, COM still accounts for ear related morbidity as patient presents late in tertiary centre like Assam Medical College. So, surgical management becomes inevitable in majority of the patients.

The term "Tubotympanic disease" is sometimes used to describe COM with a central perforation.

This term stems from the fact that the TM defect exposes both the middle ear mucosa and eustachian tube (ET), but generally does not produce inflammatory changes in the mastoid.

The two principal aims of management of tubotympanic chronic otitis media are the eradication of infection and improvement of hearing by the closure of the tympanic membrane perforation.

This can be achieved either conservatively or by surgical approach. Conservative measures aim to achieve dry ear \& limit the infection or inflammation by aural toilet and antimicrobial therapy.

The priorities of surgery in tubotympanic chronic otitis media are (1) eradication of disease, (2) prevention of disease recurrence, and (3) preservation or restoration of hearing. ${ }^{5}$

The surgical treatment of CSOM is still controversial. Some surgeons advice only repair of central perforation of tympanic membrane in non-cholesteatomatous tubotympanic chronic otitis media using graft i.e. myringoplasty to achieve a dry ear with improved hearing.

Different TM reconstruction techniques for tympanoplasty using different types of grafts, including temporalis fascia, perichondrium, palisade cartilage and cartilage island, have been described. $4,6,7,8$

The various surgical approaches to tympanoplasty include endomeatal (per meatal), endaural, and postauricular routes. ${ }^{4}$

This study aims to evaluate the outcome of myringoplasty based on closure of TM perforation and hearing improvement and various factors affecting the surgical outcome.

\section{MATERIALS AND METHODS}

This hospital-based prospective study was conducted in the Department of ENT-Head and Neck Surgery, Assam Medical College and Hospital, Dibrugarh, Assam for a period of 1 year

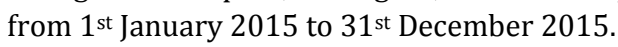

\section{Aims and Objectives}

To evaluate the surgical outcomes and various factors determining the success of myringoplasty in tubotympanic type of chronic otitis media.

\section{Selection of Cases}

All the cases of tubotympanic type of COM not responding to conservative management attending the Dept. of ENT, Assam Medical College \& Hospital, Dibrugarh fulfilling the inclusion and exclusion criteria were included in this study.

\section{Inclusion Criteria}

All the patients diagnosed as tubotympanic type of chronic otitis media with history of discharging ear with central type of tympanic membrane perforation and conductive type of hearing loss with disease-free normal middle-ear cavity \& mastoid with patent eustachian tube were included in the study irrespective of age, sex, religion, caste, literacy, geographic location, socio-economic profile \& duration of illness after dry ear was achieved conservatively for minimum 4 weeks.

\section{Exclusion Criteria}

1. CSOM with cholesteatoma, retraction pockets, granulation tissue, marginal \& total perforations, polyp in the ear, oedematous and unhealthy middle ear mucosa \& ossicular pathology, sensorineural or mixed hearing loss and with complications.

2. Patients with past history of previous ear surgery i.e. mastoidectomy or myringoplasty, etc.

3. Patients with concomitant illness like any infections of nose, paranasal sinus, nasopharynx or throat, otitis externa, uncontrolled diabetes and hypertension, psychiatric ailments, neurological disorder \& immunocompromised status.

\section{Methodology}

- All the patients were subjected to detail history, complete general, systemic and ENT examination after taking proper informed and written consent.

- ENT examination included otoscopy, tuning fork tests, eustachian tube patency test (done by inflation-deflation test and impedance audiometry), EUM (Examination under microscope) \& audiometric investigation in the form of PTA (Pure Tone Audiometry).

- Radiological investigations included X-ray mastoid (Law's lateral oblique view) \& HRCT scan of temporal bone both axial and coronal cut for detailed anatomical evaluation of eustachian tube patency and aditus patency.

- $\quad$ All the cases were initially managed conservatively by aural toileting, antibiotics, antihistaminic and decongestants in order to achieve dry ear for minimum duration of 4 weeks.

- $\quad$ All the cases were prepared for surgery by performing required investigations under general anaesthesia and local anaesthesia according to patient's wish. However, general anaesthesia was used in children and excessively apprehensive patients.

\section{Postoperative Care}

Antibiotic prophylaxis was given to all patients, started from the day prior to surgery and continued till $5^{\text {th }}$ post-operative day. External mastoid dressing was removed next day after surgery. Patients were discharged $5^{\text {th }}$ post-operative day with advice to take oral antibiotics, antihistaminic, nasal decongestants and analgesics if required. Patients were asked to attend OT for stitch removal and ear pack removal on $10^{\text {th }}$ post-operative day.

Water precautions were maintained for six weeks and patients were advised to abstain from forceful nose blowing, exposure to cold and swimming. 


\section{Followup}

For every Case, Post-operative Followup was done on-

- $1^{\text {st }}$ review- $10^{\text {th }}$ day.

- $\quad 2^{\text {nd }}$ review- $3^{\text {rd }}$ week.

- $3^{\text {rd }}$ review- $12^{\text {th }}$ week.

Surgical success was measured in terms of successful graft uptake, ability to achieve dry ear and improvement in hearing.

During each followup, every patient underwent otoscopy \& EUM to assess the graft uptake/graft rejection or reperforation, presence or absence of any ear discharge (dry ear achieved or not). During the $3^{\text {rd }}$ followup, audiological assessment was done in the form of PTA (Pure tone audiometry) and the change in the speech frequencies of 500 , 1000, $2000 \mathrm{~Hz}$ was noted. The findings were recorded and analysed to evaluate post-operative hearing improvement by calculating pre-operative \& post-operative Air-Bone Gap (ABG) and post-operative hearing gain in decibel.

Factors associated with failure to achieve successful graft uptake and dry ear were assessed in terms of clinicoepidemiological factors like extremity of ages, sex, laterality of disease, socio-economic status, presence of infection like eustachian dysfunction, URTI, otitis externa, size of tympanic membrane perforation, status of pneumatisation of mastoid, expertise of surgeon conducting myringoplasty.

\section{Statistical Analysis}

Statistical analyses were done in terms of percentage (\%) \& Mean + Standard Deviation (S.D.). Factors associated with surgical outcomes of tympanoplasty have been assessed in term of "p value" in order to determine whether they are significant or not. $\mathrm{P}$ value of the factors have been calculated by chi-square test and figured out in the corresponding tables. The software used for calculating $p$ value is Software Graphpad Inc 2017.

\section{RESULTS}

30 cases of tubotympanic variant of CSOM after fulfilling inclusion and exclusion criteria underwent myringoplasty. Success of myringoplasty was measured in terms of hearing gain, graft uptake and dry ear. Factors associated with failure of myringoplasty were then subsequently evaluated.

\begin{tabular}{|c|c|c|c|c|c|c|c|c|}
\hline \multirow[b]{2}{*}{$\begin{array}{l}\text { Age } \\
\text { Group }\end{array}$} & \multicolumn{2}{|c|}{ Total Cases } & \multicolumn{3}{|c|}{ Graft Uptake } & \multicolumn{3}{|c|}{ Dryness of Ear } \\
\hline & No. & Percentage & $\begin{array}{c}\text { Successful } \\
\text { Cases }\end{array}$ & $\begin{array}{c}\text { Failure } \\
\text { Cases }\end{array}$ & $P$ value & $\begin{array}{l}\text { Successful } \\
\text { Cases }\end{array}$ & $\begin{array}{c}\text { Failure } \\
\text { Cases }\end{array}$ & $P$ value \\
\hline$<10$ & - & & - & - & \multirow{6}{*}{$\begin{array}{c}P=.667478 \\
(N S)\end{array}$} & - & - & \multirow{6}{*}{$\begin{aligned} \mathrm{P}= & .454981 \\
& (\mathrm{NS})\end{aligned}$} \\
\hline $11-20$ & 4 & 13.33 & 3 & 1 & & 3 & 1 & \\
\hline $21-30$ & 8 & 26.67 & 8 & - & & 8 & & \\
\hline $31-40$ & 9 & 30 & 8 & 1 & & 8 & 1 & \\
\hline $41-50$ & 4 & 13.33 & 3 & 1 & & 4 & - & \\
\hline$>51$ & 5 & 16.67 & 3 & 2 & & 3 & 2 & \\
\hline
\end{tabular}

In our study, maximum number of patients ( 9 cases i.e. $30 \%$ ) belonged to the age group 31-40 years, followed by age group 21 30 years $(26.67 \%$ cases). 5 cases belonged to the age group $>51$ years while 4 cases belonged to the age group 11-20 years and 41 50 years. The mean age group was $35.16 \pm 12.75$ years.

In our study, we observed that 5 cases had graft failure at the end of $12^{\text {th }}$ post-operative week. 2 cases were more than 51 years of age while 1 case each belonged to $41-50,31-40$ and 11-20 years of age. However, $p$ value is 0.667478 which is statistically not significant.

4 cases failed to achieve dry ear at the end of $12^{\text {th }}$ post-operative week. 2 cases were more than 51 years of age. 1 case each belonged to $31-40$ and 11-20 years of age. P value is 0.454981 which is statistically not significant.

\begin{tabular}{|c|c|c|c|c|c|c|c|c|}
\hline \multirow[b]{2}{*}{ Sex } & \multicolumn{2}{|c|}{ Total Cases } & \multicolumn{3}{|c|}{ Graft Uptake } & \multicolumn{3}{|c|}{ Dryness of Ear } \\
\hline & No. & Percentage & $\begin{array}{l}\text { Successful } \\
\text { Cases }\end{array}$ & $\begin{array}{c}\text { Failure } \\
\text { Cases }\end{array}$ & $P$ value & $\begin{array}{c}\text { Successful } \\
\text { Cases }\end{array}$ & $\begin{array}{c}\text { Failure } \\
\text { Cases }\end{array}$ & $P$ value \\
\hline Male & 12 & $40 \%$ & 10 & 2 & \multirow{2}{*}{$\begin{array}{c}\mathrm{P}=1.000 \\
(\mathrm{NS})\end{array}$} & 11 & 1 & \multirow{2}{*}{$\begin{array}{c}\mathrm{P}=.510671 . \\
\quad(\mathrm{NS})\end{array}$} \\
\hline Female & 18 & $60 \%$ & 15 & 3 & & 15 & 3 & \\
\hline
\end{tabular}

In our study, $40 \%$ cases were male while $60 \%$ were female. 2 males failed to achieve successful graft uptake while 3 females failed to achieve graft uptake. P value is 1.000 which is statistically not significant. 1 male failed to achieve dry ear while 3 cases failed to achieve dry ear. P value is 0.510671 which is statistically not significant.

\begin{tabular}{|c|c|c|c|c|c|c|c|c|}
\hline \multirow{2}{*}{$\begin{array}{c}\text { Type of } \\
\text { Population }\end{array}$} & \multicolumn{2}{|c|}{ Total Cases } & \multicolumn{3}{|c|}{ Graft Uptake } & \multicolumn{3}{|c|}{ Dryness of Ear } \\
\hline & No. & Percentage & $\begin{array}{l}\text { Successful } \\
\text { Cases }\end{array}$ & $\begin{array}{c}\text { Failure } \\
\text { Cases }\end{array}$ & $P$ value & $\begin{array}{l}\text { Successful } \\
\text { Cases }\end{array}$ & $\begin{array}{c}\text { Failure } \\
\text { Cases }\end{array}$ & $P$ value \\
\hline Rural & 21 & $70 \%$ & 18 & 3 & \multirow{2}{*}{$\begin{array}{c}\mathrm{P}=.59298 \\
(\mathrm{NS})\end{array}$} & 19 & 2 & \multirow{2}{*}{$\begin{aligned} \mathrm{P}= & .348443 \\
& (\mathrm{NS})\end{aligned}$} \\
\hline Urban & 9 & $30 \%$ & 7 & 2 & & 7 & 2 & \\
\hline
\end{tabular}


In our study, 21 cases (70\%) cases belonged to rural population while 9 cases (30\%) belonged to urban population. 3 cases of rural population and 2 cases of urban population failed to achieve graft uptake. P value is 0.59298 , statistically not significant. 2 cases each of rural and urban population failed to achieve dry ear. P value is 0.34843 which is statistically not significant.

\begin{tabular}{|c|c|c|c|c|c|c|c|c|}
\hline \multirow[b]{2}{*}{ Class } & \multicolumn{2}{|c|}{ Total Cases } & \multicolumn{3}{|c|}{ Graft Uptake } & \multicolumn{3}{|c|}{ Dryness of Ear } \\
\hline & No. & Percentage & $\begin{array}{l}\text { Successful } \\
\text { Cases }\end{array}$ & $\begin{array}{c}\text { Failure } \\
\text { Cases }\end{array}$ & $P$ value & $\begin{array}{l}\text { Successful } \\
\text { Cases }\end{array}$ & $\begin{array}{c}\text { Failure } \\
\text { Cases }\end{array}$ & $P$ value \\
\hline Class I & 3 & 10 & 3 & - & \multirow{5}{*}{$\begin{array}{c}\mathrm{P}=.667478 \\
(\mathrm{NS})\end{array}$} & 3 & - & \multirow{5}{*}{$\begin{array}{c}P=.00213 \\
(N S)\end{array}$} \\
\hline Class II & 5 & 16.67 & 5 & - & & 5 & - & \\
\hline Class III & 11 & 36.67 & 10 & 1 & & 10 & 1 & \\
\hline Class IV & 9 & 30 & 7 & 2 & & 8 & 1 & \\
\hline Class V & 2 & 6.67 & 0 & 2 & & 0 & 2 & \\
\hline & & lble 4. So & ic Statu & ts Ass & n witl & of Myrin & & \\
\hline
\end{tabular}

In our study, socio-economic status was based on Modified B.G. Prasad Socio-economic classification. ${ }^{9} 11$ patients i.e. $36.67 \%$ patients belonged to class III followed by class IV, class II, class I and class V. Total of 5 cases failed to achieve successful graft uptake. The $p$ value is 0.6674 which is statistically not significant. Similarly, 4 cases failed to achieve dryness of ear ( $p=.00213$ statistically not significant).

\begin{tabular}{|c|c|c|c|c|c|c|c|c|}
\hline & \multicolumn{2}{|c|}{ Total Cases } & \multicolumn{3}{|c|}{ Graft Uptake } & \multicolumn{3}{|c|}{ Dryness of Ear } \\
\hline & No. & Percentage & $\begin{array}{c}\text { Successful } \\
\text { Cases }\end{array}$ & $\begin{array}{c}\text { Failure } \\
\text { Cases }\end{array}$ & $P$ value & $\begin{array}{c}\text { Successful } \\
\text { Cases }\end{array}$ & $\begin{array}{c}\text { Failure } \\
\text { Cases }\end{array}$ & $P$ value \\
\hline Unilateral & 24 & $60 \%$ & 22 & 2 & $\begin{array}{l}\mathrm{P}=.01430 \\
\text { significant }\end{array}$ & 23 & 1 & $\begin{array}{l}\mathrm{P}=.00313 \\
\text { significant }\end{array}$ \\
\hline Bilateral & 6 & 20 & 3 & 3 & & 3 & 3 & \\
\hline
\end{tabular}

In this study, 24 cases had unilateral presentation of CSOM. (16 cases in the left ear while 8 cases in the right ear). 6 cases (20\%) had clinical presentation in the right ear and both ears respectively. 22 cases with unilateral presentation and 3 cases of bilateral presentation had successful graft uptake while 2 cases with unilateral presentation and 3 cases of bilateral presentation respectively failed to achieve successful graft uptake. The p value is 0.01430 which is statistically significant. Similarly, 23 cases with unilateral presentation and 3 cases of bilateral presentation achieved dry ear while 1 case with unilateral presentation and 3 cases of bilateral presentation respectively failed to achieve dry ear. The p value is 0.00313 which is statistically significant.

\begin{tabular}{|c|c|c|c|c|c|c|c|c|}
\hline \multirow{2}{*}{$\begin{array}{l}\text { Type of TM } \\
\text { Perforation }\end{array}$} & \multicolumn{2}{|c|}{ Total Cases } & \multicolumn{3}{|c|}{ Graft Uptake } & \multicolumn{3}{|c|}{ Dryness of Ear } \\
\hline & No. & Percentage & $\begin{array}{l}\text { Successful } \\
\text { Cases (25) }\end{array}$ & $\begin{array}{c}\text { Failure } \\
\text { Cases (5) }\end{array}$ & $P$ value & $\begin{array}{l}\text { Successful } \\
\text { Cases (26) }\end{array}$ & $\begin{array}{c}\text { Failure } \\
\text { Cases(4) }\end{array}$ & $P$ value \\
\hline $\begin{array}{c}\text { Small sized } \\
(<25 \%)\end{array}$ & - & & - & - & \multirow{4}{*}{$\begin{array}{c}P=.61093 \\
(N S)\end{array}$} & - & - & \multirow{4}{*}{$\begin{array}{c}P=.268925 \\
(N S)\end{array}$} \\
\hline $\begin{array}{c}\text { Medium (25- } \\
50 \%)\end{array}$ & 8 & 26.67 & 8 & - & & 8 & - & \\
\hline Large (50-75\%) & 11 & 36.67 & 9 & 2 & & 10 & 1 & \\
\hline $\begin{array}{l}\text { Subtotal } \\
(>75 \%)\end{array}$ & 11 & 36.67 & 8 & 3 & & 8 & 3 & \\
\hline
\end{tabular}

In our study, 11 cases had large and sub-total perforation each followed by 8 cases of medium TM perforation. 9 cases with large TM perforation and 8 cases of sub-total TM perforation had successful graft uptake while 2 cases with large perforation and 3 cases of sub-total perforation failed to achieve graft uptake. The p value is 0.61093 which is statistically not significant. 8 cases with sub-total perforation and 10 cases of large TM perforation had dryness of ear while 2 cases with large perforation and 3 cases of sub-total perforation failed to achieve dry ear. The $p$ value is 0.268925 which is statistically not significant.

\begin{tabular}{|c|c|c|c|c|c|c|c|c|}
\hline \multirow{2}{*}{$\begin{array}{c}\text { Type of } \\
\text { Mastoid } \\
\text { Cellularity }\end{array}$} & \multicolumn{2}{|c|}{ Total Cases } & \multicolumn{3}{|c|}{ Graft Uptake } & \multicolumn{3}{c|}{ Dryness of Ear } \\
\cline { 2 - 9 } & No. & Percentage & $\begin{array}{c}\text { Successful } \\
\text { Cases (25) }\end{array}$ & $\begin{array}{c}\text { Failure } \\
\text { Cases (5) }\end{array}$ & P value & $\begin{array}{c}\text { Successful } \\
\text { Cases (26) }\end{array}$ & $\begin{array}{c}\text { Failure } \\
\text { Cases (4) }\end{array}$ & P value \\
\hline Pneumatic & 7 & 23.33 & 7 & - & P $=.61093$ & 7 & - & \multirow{2}{*}{$\begin{array}{c}\text { P }=.65869 \\
\text { (NS) }\end{array}$} \\
\hline Sclerotic & 19 & 63.33 & 15 & 4 & 16 & 3 \\
\hline Diploic & 4 & 13.33 & 3 & 1 & & 3 & 1 \\
\hline
\end{tabular}

The study included 19 cases of sclerotic mastoid, 7 cases of pneumatic mastoid and 4 cases of diploic mastoid. 15 cases of sclerotic mastoid and 3 cases of diploic mastoid had successful graft uptake while 4 cases of sclerotic mastoid and 1 case of diploic mastoid failed to achieve graft uptake. The p value is 0.61093 (statistically not significant). Similarly, 16 cases of sclerotic mastoid and 3 cases of diploic mastoid had dry ear while 4 cases of sclerotic mastoid and 1 case of diploic mastoid failed to achieve dry ear. The $\mathrm{p}$ value is 0.65869 (statistically not significant). 


\begin{tabular}{|c|c|c|c|c|c|c|c|c|}
\hline \multirow[b]{2}{*}{ Surgeon } & \multicolumn{2}{|c|}{ Total Cases } & \multicolumn{3}{|c|}{ Graft Uptake } & \multicolumn{3}{|c|}{ Dryness of Ear } \\
\hline & No. & Percentage & $\begin{array}{l}\text { Successful } \\
\text { Cases (25) }\end{array}$ & $\begin{array}{c}\text { Failure Cases } \\
\text { (5) }\end{array}$ & $P$ value & $\begin{array}{l}\text { Successful } \\
\text { Cases (26) }\end{array}$ & $\begin{array}{c}\text { Failure } \\
\text { Cases (4) }\end{array}$ & $P$ value \\
\hline $\begin{array}{c}\text { Senior } \\
\text { consultant }\end{array}$ & 15 & 50 & 13 & 2 & \multirow{2}{*}{$\begin{aligned} \mathrm{P}= & .624206 \\
& (\mathrm{NS})\end{aligned}$} & 14 & 1 & \multirow{2}{*}{$\begin{array}{c}P=.63256 \\
\quad(N S)\end{array}$} \\
\hline $\begin{array}{l}\text { Junior } \\
\text { resident }\end{array}$ & 15 & 50 & 12 & 3 & & 12 & 3 & \\
\hline
\end{tabular}

Out of 5 cases of graft failure, 2 cases were conducted by senior consultant while 3 cases were conducted by junior resident. The $\mathrm{p}$ value is 0.624206 (statistically not significant). Similarly, out of 4 cases which failed to achieve dry ear, 1 case was conducted by senior consultant while 3 cases were conducted by junior resident.

\begin{tabular}{|c|c|c|}
\hline $\begin{array}{c}\text { Association with } \\
\text { Infection }\end{array}$ & $\begin{array}{c}\text { Association with } \\
\text { Cases } \\
\text { of Graft Failure }\end{array}$ & $\begin{array}{c}\text { Association with } \\
\text { Cases of } \\
\text { Failure to Achieve } \\
\text { Dry Ear }\end{array}$ \\
\hline ET dysfunction & $4(80 \%)$ & $4(100 \%)$ \\
\hline URTI & $3(60 \%)$ & $4(100 \%)$ \\
\hline Otitis externa & $1(20 \%)$ & $3(75 \%)$ \\
\hline \multicolumn{2}{|c|}{ Table 9. Association of Infection Post-operatively } \\
\hline
\end{tabular}

Out of 5 cases of graft failure, 4 cases had ET dysfunction post-operatively, 3 cases had URTI and 1 case had otitis externa. Similarly, 4 cases had ET dysfunction and URTI each in the cases with failure to achieve dry ear and 3 cases had otitis externa.

\begin{tabular}{|c|c|}
\hline & $\mathrm{N}=\mathbf{3 0}$ \\
\hline Mean preoperative ABG & $31.766 \pm 3.94 \mathrm{~dB}$ \\
\hline $\begin{array}{l}\text { Mean post-operative ABG at } \\
3^{\text {rd }} \text { followup }\end{array}$ & $21.866 \pm 4.98 \mathrm{~dB}$ \\
\hline Gain in hearing & $9.90 \pm 1.81 \mathrm{~dB}$ \\
\hline \multicolumn{2}{|c|}{$\begin{array}{l}\text { Table 10. Audiological Assessment Preoperatively and at } \\
3^{\text {rd }} \text { Followup (12 }\left(12^{\text {th }} \text { week) }\right.\end{array}$} \\
\hline
\end{tabular}

In our study, we found that mean gain in hearing postoperatively at $3^{\text {rd }}$ followup i.e., 12 weeks was $9.90 \pm 1.81 \mathrm{~dB}$.

\section{DISCUSSION}

This study was conducted in 30 patients of tubotympanic type of chronic suppurative otitis media after fulfilling inclusion and exclusion criteria. All the cases underwent myringoplasty. Epidemiological, clinical profile, surgical outcomes and factors responsible for failure were studied during post-operative followup.

In our study, mean age was $35.16 \pm 12.75$ years. Highest number of patients i.e. $30 \%$ belonged to the age group of 31 40 years followed by age group $21-30$ years (26.67\% cases).

Indorewala et al in their study found that the age of the patients ranged from 5 to 76 years, with a mean age of $35 \pm$ 15.8 years; the age group 21-40 years was the most affected group (36\%).4 Our findings correlate with this particular study.

Our study found sex ratio of 2:3 (40\% male and 60\% female). However, Browning et al found the incidence of CSOM to be $1.9 \%$ in males and $1.2 \%$ in females. ${ }^{10} \mathrm{~A}$ sex ratio of 1.3 to 1 was found by M.A Yaor et al in their study. ${ }^{11}$

In our study, $70 \%$ cases belonged to rural population while $30 \%$ belonged to urban population. In a study by Islam et al, distribution of habitat of the patients were found to be $65.33 \%$ from rural area $\& 34.67 \%$ from urban area. ${ }^{12}$ Our study is in correlation with this study.
The study by Maharjan et al reflected that the prevalence of CSOM is similar in rural communities of Nepal, Bangladesh and aboriginal children of Northern and central Australia. Probably, the habit of swimming in polluted water in a pond or river regularly may be a factor responsible for discharging ear. ${ }^{13}$

The reason for higher incidence in the rural area could be due to lower standard living, poor hygiene, malnutrition, illiteracy, negligence on the part of patient and family members and lack of proper medical facilities in the rural areas.

In our study, socio-economic status was based on modified B.G. Prasad Socio-economic classification. ${ }^{9}$ 36.67\% patients belonged to class III followed by class IV (30\%), class II (16.67\%), class I (10\%) and class V (6.67\%).

This leads to the inference that lower socio-economic living status is an important contributing and predisposing factor in chronic otitis media.

Acuin in the study has described CSOM to be commonly associated with poor socio-economic status or povertyrelated conditions such as malnutrition, over-crowding, substandard hygiene, frequent upper respiratory tract infections and under-resourced health care. ${ }^{14}$

Couzos $\mathrm{S}$ et al has also concluded that ear diseases have a higher prevalence in communities of low socio-economic status due to their poor living conditions. ${ }^{15}$

In this study, $53.33 \%$ cases had clinical presentation in the left ear. $26.67 \%$ and $20 \%$ patients had clinical presentation in the right ear and both ears respectively. Similar to our study, Shivakumar et al also found that left side was more commonly involved the right side. Bilateral TM perforation was seen in $24 \% .{ }^{16}$ However, no explanation has been given for more involvement of left ear than right ear.

Saha et al in their study found bilateral ear disease in $30 \%$ cases. Right ear disease was in $20 \%$ and left ear disease was in $50 \%$ of the cases. ${ }^{17}$

In the present study, $36.67 \%$ cases each had large and subtotal perforation followed by medium perforation in $26.67 \%$. However, Kumar et al in their study observed that $43.75 \%$ had moderate TM perforation, $14.06 \%$ had large TM perforation and $32.81 \%$ had subtotal TM perforation. ${ }^{18}$ Shivakumar et al observed that $57 \%$ of the cases had medium-sized perforation while small perforation was seen in $43 \%$ of the cases. ${ }^{16}$

The study included $63.33 \%$ cases of sclerotic mastoid, $23.33 \%$ cases of pneumatic mastoid and $13.33 \%$ cases of diploic mastoid. Sunita et al observed that on x-ray, mastoids, pneumatisation was seen in $30 \%$, diploic in $8 \%$, sclerosed mastoid in $54 \%$ and cavity in $8 \%$ of the cases. On HRCT 
temporal bone, pneumatisation was seen in 38\%, diploic in $4 \%$, sclerosed in $50 \%$ and cavity in $8 \%$ of the cases. ${ }^{19}$

In our study, we found that mean pre-operative $A B G$ was $31.766 \pm 3.94 \mathrm{~dB}$ while mean post-operative $\mathrm{ABG}$ at $3^{\text {rd }}$ followup (12 th week) was $21.866 \pm 4.98 \mathrm{~dB}$. So gain in hearing was $9.90 \pm 1.81 \mathrm{~dB}$. Kamath et al observed that pre-operative mean $\mathrm{ABG}$ in the group undergoing myringoplasty was 34.69 $\pm 11.6 \mathrm{~dB}$ while post-operative $\mathrm{ABG}$ at $3^{\text {rd }}$ month was $23.82 \pm$ $1039 \mathrm{~dB} .{ }^{1}$ The hearing improvement was $11.45 \pm 5.53 \mathrm{~dB} .{ }^{1}$ This finding is in correlation to our study. In the study by Kaur $^{20}$ et al, post-operative ABG was $27.72 \pm 7.197 \mathrm{~dB}$ in group undergoing tympanoplasty. The benefit of hearing was $7.64 \pm 5.787 . .^{2}$ Krishnan et al assessed that the post-operative $\mathrm{ABG}$ was $17.9 \pm 7.01 \mathrm{~dB}$ in patients undergoing myringoplasty. ${ }^{21}$

In our study, successful graft uptake at $12^{\text {th }}$ postoperative week was seen in 25 cases (83.33\%). Graft failure was seen in 5 cases. Kamath et al observed that graft success rates were $80 \%$ in patients undergoing myringoplasty. ${ }^{1}$ In the study conducted by Kaur et al, graft uptake was observed in $76 \%$ of cases undergoing myringoplasty. ${ }^{20}$ In the study by Mishiro et al, graft success rates were $93.3 \%$ in group of tympanoplasty. ${ }^{22}$ Balyan et al in the study observed that successful graft uptake was seen in $89.2 \%$ cases undergoing myringoplasty. ${ }^{23}$

In our study, we observed that 26 cases achieved dry ear at the end of $12^{\text {th }}$ post-operative week. Analysis of the 4 cases which presented with post-operative otorrhoea revealed that 2 cases were more than 51 years of age. 3 cases were female and 1 case was male. 3 cases had bilateral ear disease. 2 cases belonged to class V, 1 case belonged each to class IV and class III of socio-economic classification. 2 cases belonged to each rural and urban population. 4 cases had ET dysfunction, 4 cases had URTI and 3 cases had associated otitis externa. 4 cases had associated graft failure. 3 cases had sub-total TM perforation while 1 case had large TM perforation. 3 cases had sclerotic mastoid while 1 case had diploic mastoid. 3 cases were conducted by junior resident while 1 case was conducted by senior consultant.

Kaur et al also described the factors associated with clinical improvement in the form of ability to achieve dry ear. They found that better Eustachian tube function, age of patient, duration of disease, discharge-free period, size of the perforation, and status of middle ear mucosa are the associated factors. Incidence of URTI has adverse effect on healing and outcome. ${ }^{20}$ Pignataro et al, however, observed that surgical outcome was not affected by the patient's age, the site and size of the perforation, previous adenoidectomy or surgical technique.1, 24 This study is similar to our findings.

While analysing the 5 cases of graft failure, it was observed that 2 cases belonged to $>51$ years of age while 1 case each belonged to 41-50, 31-40 and 11-20 years of age. 3 cases had disease in the both ears. 2 cases belonged each to class V and class IV socio-economic group while 1 case belonged to class III. 3 cases belonged to rural setup while 2 cases belonged to urban population. 4 cases had associated ET dysfunction while 3 cases had URTI and 1 case had otitis externa. 4 cases had associated ear discharge. It was observed that 3 cases had sub-total TM perforation while 2 cases had large TM perforation. 4 cases had sclerotic mastoid while 1 case had diploic mastoid. 2 cases of graft failure were operated by senior consultants while 3 cases were conducted by junior residents.
Kolo et al in their study found that increasing age was an unfavourable prognostic factor in determining the postoperative hearing results after primary tympanoplasty. The reason for this was not very apparent. Perhaps, this could possibly be due to the phenomenon of delayed wound healing in the older age group. As a result, this might have affected the sound transmitting dynamics of the middle ear. ${ }^{25}$

In a study conducted by Vartanien, ${ }^{26}$ reperforations and graft failure were significantly more often in larger perforations sized $>50 \%$ of drum area compared to smaller perforations $(<50 \%)$. This could probably be due to poorer vascular supply to a larger graft as a larger area of graft remains unsupported in space. ${ }^{26}$ Aggarwal et al in their study observed higher success rates with smaller perforations (less than $50 \%$ of pars tensa). ${ }^{27}$

Yoon et al in their study concluded that there were no significant relationships between surgical success rate and the status of the contralateral ear. ${ }^{28}$ But Merendra et al reported that multivariate analysis demonstrated that disease of the contralateral ear and a large tympanometric volume were statistically significant. ${ }^{29}$ This study is similar to our study.

Most failure cases were associated with nidus of infection in the upper respiratory tract. Smith and Vaughan et al suggested that nasal bacterial load should be reduced in order to control the incidence of suppurative otitis media. ${ }^{30}$

Albu et al found that three factors were significant in predicting success rate, i.e. healthy opposite ear, a long dry period preceding the operation, and non-smoker status. The only factor attaining significance in the multivariate analysis was a dry period longer than 3 months. 31,32

From the above findings, we can conclude that lower socio-economic status particularly in rural population, upper respiratory tract infection with ET dysfunction, disease in contralateral ear are associated with failure of surgical outcome of tympanometry in tubotympanic type of chronic otitis media in our study. But size of TM perforation, sclerotic mastoid, extremity of ages and surgical expertise are not significant factors ( $p$ value statistically not significant) determining the success of tympanometry in tubotympanic type of chronic otitis media in our study.

\section{CONCLUSION}

Chronic otitis media still constitutes a major public health problem in general population of the districts of upper Assam. Goal of surgical management of tubotympanic type of $\mathrm{COM}$ is to close the tympanic membrane perforation and clinical improvement in the form of gain in hearing postoperatively and discharge-free ear. Myringoplasty is an effective method of treatment of chronic ear infection resistant to antibiotic therapy. Success of myringoplasty is measured in terms of gain in hearing, graft uptake and achieving a dry ear.

Our study acknowledges that successful outcome of surgery is determined by a range of anatomical, physiological, pathological and epidemiological factors and lower socioeconomic status, particularly in rural population with unhygienic living conditions. $70 \%$ cases belonged to rural areas and 4 cases belonging to lower socio-economic class (Class IV and class V) failed to have successful graft uptake and 3 cases of class IV and class $V$ failed to achieve dry ear. Presence of nidus of infection in the upper airway ( $60 \%$ cases of graft failure and $100 \%$ cases of failure to achieve dry ear) 
along with eustachian tube dysfunction (80\% cases of graft failure and $100 \%$ cases of failure to achieve dry ear), otitis externa ( $20 \%$ cases of graft failure and $75 \%$ cases of failure to achieve dry ear), disease in contralateral ear $(50 \%$ cases of graft failure and $75 \%$ cases of failure to achieve dry ear with bilateral ear disease) may be considered as some of the possible factors responsible for influencing the outcomes of surgery in tubotympanic type of chronic otitis media. But we emphasise that more cases or study population for longer durations should be studied to draw a conclusion.

\section{REFERENCES}

[1] Kamath MP, Sreedharan S, Rao AR, et al. Success of myringoplasty: our experience. Indian J Otolaryngol Head Neck Surg 2013;65(4):358-62.

[2] Smyth GD. Tympanic reconstruction. Fifteen year report on tympanoplasty. Part II. J Laryngol Otol 1976;90(8):713-41.

[3] WHO. Chronic suppurative otitis media burden of illness and management options. Geneva: World Health Organization 2004.

[4] Indorewala S, Adedeji TO, Indorewala A, et al. Tympanoplasty outcomes: a review of 789 cases. Iran J Otorhinolaryngol 2015;27(79):101-8.

[5] Haynes D. Canal wall up mastoidectomy. In: Gulya A, (edr). Glasscock-Shambaugh surgery of the ear. $6^{\text {th }}$ edn. Shelton, Connecticut 2010:501-14.

[6] Kazikdas KC, Onal K, Boyraz I, et al. Palisade cartilage tympanoplasty for management of subtotal perforations: a comparison with the temporalis fascia technique. Eur Arch Otorhinolaryngol 2007;264(9):985-9.

[7] Demirpehlivan IA, Onal K, Arslanoglu S, et al. Comparison of different tympanic membrane reconstruction techniques in type I tympanoplasty. Eur Arch Otorhinolaryngol 2011;268(3):471-4.

[8] Mauri M, Neto LJF, Fuchs SC. Evaluation of inlay butterfly cartilage tympanoplasty: a randomized clinical trial. Laryngoscope 2001;111(8):1479-85.

[9] Mangal A, Kumar V, Panesar S, et al. Updated BG Prasad socioeconomic classification, 2014: a commentary. Indian J of Public Health 2015;59(1):424.

[10] Browning GG, Gatehouse S, Calder IT. Medical management of active chronic otitis media: a controlled study. J Laryngol Otol 1988;102(6):491-5.

[11] Yaor MA, El-Kholy A, Jafari B. Surgical management of chronic suppurative otitis media: a 3 year experience. Annals of African medicine 2006;5(1):24-7.

[12] Islam MS, Islam R, Bhuiyan MAR. Pattern \& degree of hearing loss in chronic suppurative otitis media. Bangladesh J Otorhinolaryngol 2010;16(2):96-105.

[13] Maharjan M, Bhandari S, Singh I, et al. Prevalence of otitis media in school going children in eastern Nepal. Kathmandu Univ Med J 2006;4(4):479-82.

[14] Acuin JM. Chronic suppurative otitis media: a disease waiting for solutions. Comm Ear Hearing $\mathrm{H}$ 2007;4(6):17-9.

[15] Couzos S, Metcalf S, Murray R. The national aboriginal community controlled health organisation (NACCHO). Systematic review of existing evidence and primary care guidelines on the management of otitis media in aboriginal and Torres strait islander populations. Canberra: office for aboriginal and Torres Strait islander health 2001.

[16] Shivakumar KL, Joshym S, Mary. Role of cortical mastoidectomy in inactive, mucosal type of chronic otitis media. Journal of evidence based medicine and healthcare 2014;1(7):509-17.

[17] Saha AK, Munsi DM, Ghosh SN. Evaluation of improvement of hearing in type I tympanoplasty \& its influencing factors. Indian $\mathrm{J}$ of Otolaryngology and Head and Neck Surgery 2006;58(3):253-7.

[18] Kumar N, Chilke D, Puttewar MP. Clinical profile of tubotympanic CSOM and its management with special reference to site and size of tympanic membrane perforation, eustachian tube function, three flap tympanoplasty. Indian J Otolaryngol Head Neck Surg 2011;64(1):5-12.

[19] Sunita M, Sambandan AP. Importance of pre-operative HRCT temporal bone in chronic suppurative otitis media. Odisha J of otorhinolaryngology \& head and neck surgery 2015;9(1):10-2.

[20] Kaur M, Singh B, Verma BS, et al. Comparative evaluation between tympanoplasty alone \& tympanoplasty combined with cortical mastoidectomy in non-cholesteatomatous chronic suppurative otitis media in patients with sclerotic bone. IOSR Journal of Dental and Medical Sciences 2014;13(6):40-5.

[21] Krishnan A, Reddy EK, Chandrakiran C, et al. Tympanoplasty with and without cortical mastoidectomy - a comparative study. Indian Journal of Otolaryngology and Head and Neck Surgery 2002;54(3):195-8.

[22] Mishiro Y, Sakagami M, Takahashi Y, et al. Tympanoplasty with and without mastoidectomy for non-cholesteatomatous chronic otitis media. Eur Arch Otorhinolaryngol 2001;258(1):13-5.

[23] Balyan FR, Celikkanat S, Aslan A, et al. Mastoidectomy in non-cholesteatomatous chronic suppurative otitis media: is it necessary? Otolaryngol Head Neck Surg 1997;117(6):592-5.

[24] Pignataro L, Berta GDL, Capaccio P, et al. Myringoplasty in children: anatomical and functional results. J Laryngol Otol 2001;115(5):369-73.

[25] Kolo ES, Ramalingam R. Hearing results post tympanoplasty: our experience with adults at the KKR ENT hospital, India. Indian J Otolaryngol Head Neck Surg 2014;66(4):365-8.

[26] Vartiainen E, Karja J, Karjalainen S, et al. Failures in myringoplasty. Arch Otorhinolaryngol 1985;242(1):27-33.

[27] Aggarwal R, Saeed SR, Green KJM. Myringoplasty. The journal of Laryngology and Otology 2006;120(6): 429-32.

[28] Yoon TH, Park SK, Kim JY, et al. Tympanoplasty, with or without mastoidectomy, is highly effective for treatment of chronic otitis media in children. Acta Otolaryngol Suppl 2007;558:44-8.

[29] Merenda D, Koike K, Shafiei M, et al. Tympanometric volume: a predictor of success of tympanoplasty in children. Otolaryngo Head Neck Surg 2007;136(2):189-92. 
[30] Smith-Vaughan H, Byun R, Nadkarni M, et al. Measuring nasal bacterial load and its association with otitis media. BMC E.N.T Disorders 2006;6:10.

[31] Albu S, Trabalzini F, Amadori M. Usefulness of cortical mastoidectomy in myringoplasty. Otol Neurotol 2012;33(4):604-9.
[32] Tawab HMA, Gharib FM, ElSharkawy LS, et al. Myringoplasty with and without cortical mastoidectomy in treatment of noncholesteatomatous chronic otitis media: a comparative study. Clinical Medicine Insights: Ear, Nose and Throat 2014;7:19-23. 